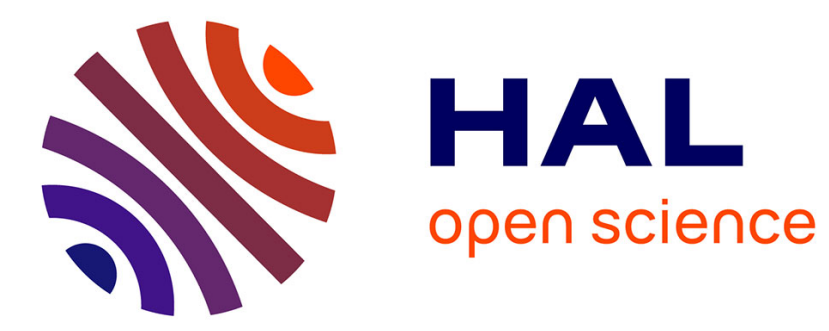

\title{
Harnessing the regulators to enhance viral vaccine efficacy
}

Jagadeesh Bayry

\section{To cite this version:}

Jagadeesh Bayry. Harnessing the regulators to enhance viral vaccine efficacy. Future Medicinal Chemistry, 2017, 9 (12), pp.1319 - 1321. 10.4155/fmc-2017-0103 . hal-01744179

\section{HAL Id: hal-01744179 \\ https://hal.sorbonne-universite.fr/hal-01744179}

Submitted on 27 Mar 2018

HAL is a multi-disciplinary open access archive for the deposit and dissemination of scientific research documents, whether they are published or not. The documents may come from teaching and research institutions in France or abroad, or from public or private research centers.
L'archive ouverte pluridisciplinaire HAL, est destinée au dépôt et à la diffusion de documents scientifiques de niveau recherche, publiés ou non, émanant des établissements d'enseignement et de recherche français ou étrangers, des laboratoires publics ou privés. 


\section{Harnessing the regulators to enhance viral vaccine efficacy}

\section{Jagadeesh Bayry ${ }^{1,2,3,4}$}

${ }^{1}$ Institut National de la Santé et de la Recherche Médicale Unité 1138, Paris, F-75006, France.

${ }^{2}$ Centre de Recherche des Cordeliers, Equipe-Immunopathologie et immunointervention thérapeutique, Paris, F-75006, France.

${ }^{3}$ Sorbonne Universités, Université Pierre et Marie Curie, Paris 06, UMR S 1138, Paris, F75006, France.

${ }^{4}$ Université Paris Descartes, Sorbonne Paris Cité, UMR S 1138, Paris, F-75006, France.

Correspondence to: Jagadeesh Bayry, Institut National de la Santé et de la Recherche Médicale, Unité 1138, Centre de Recherche des Cordeliers, 15 rue de l'Ecole de Médicine, Paris, F-75006, France. Tel: 00331442782 03; Fax: 00331442781 94. E-mail: jagadeesh.bayry@crc.jussieu.fr 


\begin{abstract}
$\mathrm{CD} 4^{+} \mathrm{CD} 25^{+} \mathrm{FoxP}^{+}$regulatory $\mathrm{T}$ cells (Tregs) are well known for their immune suppressive functions. While these tasks are important for maintaining immune tolerance and to prevent autoimmune and inflammatory diseases, suppression of innate and adaptive immune cells also leads to diminished immune response to vaccines including viral vaccines. Experimental models based on Treg depletion methods provided proof of concept that Tregs have negative impact on vaccine response. However such methodologies lack translational values due to adverse effects of Treg depletion. Therefore, targeting Tregs for vaccination purposes should aim at their transient inhibition of activities while keeping homeostatic functions intact.
\end{abstract}

Key Words: Regulatory T cells, Treg, vaccine, virus, immune response 
Maintaining the immune homeostasis is important for preventing autoimmune and inflammatory diseases. Although several players are in place to ensure disease free status of an individual, $\mathrm{CD} 4^{+} \mathrm{CD} 25^{+} \mathrm{FoxP}^{+}$regulatory $\mathrm{T}$ cells or classically known as 'Tregs' have a major role in this process. These Tregs are either thymus-derived or generated in the periphery. The thymus-derived Tregs are self-antigen specific while Tregs towards foreign antigens are mostly derived in the periphery. The current evidence clearly shows that Tregs are not dependent on one single mechanism rather enforce immune tolerance via mutually non-excusive mechanisms. For that matter, the arms of Tregs are quite long and extend their influence virtually on each and every cell of the immune system: both innate (like dendritic cells, macrophages, neutrophils and monocytes) and adaptive immune cells ( $\mathrm{T}$ cell subsets and $\mathrm{B}$ cells) [1]. Thus, it is conceivable that Tregs regulate all steps of immune response starting from antigen recognition, presentation and initiation of cellular and humoral immune responses, both during primary and memory immune responses. While these functions virtually shut down autoimmune and inflammatory responses, suppressive effects of Tregs on immune cells also negatively influence protective immune response to pathogens and vaccines [2-4].

Several studies have shown that Tregs although important in acute viral infection to reduce inflammation-associated tissue damage [5], they enhance viral persistence in chronic viral infections and reduce anti-viral immune responses [2, 6-9]. Similarly, Tregs also hamper immune response to viral vaccines and their depletion leads to significant improvement in the protective responses as shown with recombinant subunit hepatitis B virus, herpes simplex virus type 1, influenza and other vaccines [10-13]. Data from humans also support these findings. In fact, following influenza vaccination, Tregs are increased post-vaccination and that post vaccination TGF- $\beta$ levels, one of the cytokines of Tregs, negatively correlate with anti-influenza antibody titers [14]. Depletion of Tregs ex vivo also enhanced Gag-specific 
$\mathrm{CD}^{+} \mathrm{T}$ cell polyfunctional response following dendritic cell-based therapeutic vaccination of HIV-1-infected patients who are on antiretroviral therapy [15]. Another study in tick-borne encephalitis virus vaccinated population revealed that $\mathrm{FoxP}^{+}$Tregs that are induced following booster vaccination might be responsible for suppression of $\mathrm{T}$ and $\mathrm{B}$ cell responses [16].

So, the burning question is how to tackle the influence of Tregs to boost protective immunity to vaccines: both intensity as well as duration of immune response, without compromising Treg role in maintaining immune tolerance. The experimental data on use of Treg depletion strategy through CD25 monoclonal antibodies gives only a proof of concept that Tregs have negative impact on vaccine response. But Treg depletion might leads to appearance of autoimmune symptoms and hence should be avoided for vaccination. In addition, in the vaccination scenario, the immune system will be in the activated state due to immune response to vaccines and hence more likelihood of breaking the immune tolerance if Tregs are depleted.

Therefore, targeting Tregs for vaccination should aim at their transient inhibition of activities without having long-term effects on their homeostasis. As monoclonal antibodies have longer half-life, their use is not appropriate for achieving this goal. On the other hand, several promising alternative approaches have been reported to transiently inhibit Tregs that can be considered for viral vaccination.

Several agonists of pattern recognition receptors such as poly(I:C), a toll-like receptor 3 (TLR3) agonist, and the CpG-ODN, a TLR9 agonist have shown to expand exclusively effector T cells over Tregs [17] and are in various stages of clinical trials for cancer vaccines [18]. 
Clinical studies have demonstrated that cyclophosphamide when used at metronomic doses, transiently reduce the frequency of Tregs without altering the functions of effector $\mathrm{T}$ cells. This strategy has been shown to enhance protective immune response to anti-tumor immunotherapy [19].

Pre-clinical models have demonstrated utility of tackling migration of Tregs at the time of vaccination. Chemokine-chemokine receptor interaction guides the migration of immune cells. Human Tregs express CCR4 and hence migrate in response to CCL22 and CCL17 secreted by activated innate cells such as dendritic cells [20]. Thus, CCR4-CCL22/CCCL17 pathway plays a critical role in leading Tregs toward innate cells and to their suppression of activation and ability to mount immune response. Therefore, we hypothesized that, if this chemokine axis is blocked transiently at the time of vaccination by using small molecule antagonists to CCR4, then immune response to vaccines could be enhanced. In fact, vaccination models of bacteria, parasite, virus (Hepatitis B virus) and tumor have shown that CCR4 antagonists when combined with vaccines, significantly enhance cellular and humoral immune responses [21-28]. Importantly, Treg number was not altered by this approach and no signs of autoimmune response was noticed [23, 29]. All these data suggest potential utility of small molecule antagonists to CCR4 for human viral vaccines.

Predetermination of Treg epitopes in vaccine antigens by in silico approach and introducing appropriate modification in the antigens represents another way to reduce Treg influence on viral vaccines [30].

Without a doubt, we have now few tools to tackle Tregs in order to boost protective immune response to viral vaccines while keeping homeostatic functions intact. It is however important to make sure that these strategies do not end up only in pre-clinical models. 


\section{Acknowledgments}

Supported by Institut National de la Santé et de la Recherche Médicale (INSERM), Université Pierre et Marie Curie, Université Paris Descartes, and the Indo-French Center for Promotion of Advanced Research (CEFIPRA). I would like to thank all my colleagues and collaborators who contributed to development of CCR4 antagonists and testing them in various models.

\section{Financial \& competing interests disclosure}

The author holds patent on small molecule CCR4 antagonists to target regulatory $\mathrm{T}$ cells in vaccination. He has no other relevant affiliations or financial involvement with any organization or entity with a financial interest in or financial conflict with the subject matter or materials discussed in the manuscript. This includes employment, consultancies, honoraria, stock ownership or options, expert testimony, grants received or pending, or royalties.

No writing assistance was utilized in the production of this manuscript. 


\section{References}

1. Sakaguchi S, Yamaguchi T, Nomura T, Ono M. Regulatory $\mathrm{T}$ cells and immune tolerance. Cell 133, 775-787 (2008).

2. Stephen-Victor E, Bosschem I, Haesebrouck F, Bayry J. The Yin and Yang of regulatory $\mathrm{T}$ cells in infectious diseases and avenues to target them. Cell Microbiol. 19, e12746 (2017). doi: 10.1111/cmi.12746

3. Boer MC, Joosten SA, Ottenhoff TH. Regulatory T-cells at the interface between human host and pathogens in infectious diseases and vaccination. Front Immunol. 6, 217 (2015).

4. Bayry J. Regulatory $\mathrm{T}$ cells as adjuvant target for enhancing the viral disease vaccine efficacy. Virusdisease 25, 18-25 (2014).

5. Stross L, Gunther J, Gasteiger G et al. Foxp3+ regulatory $\mathrm{T}$ cells protect the liver from immune damage and compromise virus control during acute experimental hepatitis B virus infection in mice. Hepatology 56, 873-883 (2012).

6. Suvas S, Kumaraguru U, Pack CD, Lee S, Rouse BT. CD4+CD25+ T cells regulate virus-specific primary and memory CD8+ T cell responses. J Exp Med. 198, 889901 (2003).

7. Dittmer U, He H, Messer RJ et al. Functional impairment of CD8+ $\mathrm{T}$ cells by regulatory T cells during persistent retroviral infection. Immunity 20, 293-303 (2004).

8. Cabrera $\mathrm{R}, \mathrm{Tu} \mathrm{Z}, \mathrm{Xu} \mathrm{Y}$ et al. An immunomodulatory role for CD4+CD25+ regulatory T lymphocytes in hepatitis C virus infection. Hepatology 40, 1062-1071 (2004).

9. Stoop JN, van der Molen RG, Baan CC et al. Regulatory $\mathrm{T}$ cells contribute to the impaired immune response in patients with chronic hepatitis $\mathrm{B}$ virus infection. Hepatology 41, 771-778 (2005).

10. Toka FN, Suvas S, Rouse BT. CD4+ CD25+ T cells regulate vaccine-generated primary and memory CD8+ T-cell responses against herpes simplex virus type 1 . J Virol. 78, 13082-13089 (2004).

11. Moore AC, Gallimore A, Draper SJ, Watkins KR, Gilbert SC, Hill AV. Anti-CD25 antibody enhancement of vaccine-induced immunogenicity: increased durable cellular immunity with reduced immunodominance. J Immunol. 175, 7264-7273 (2005).

12. Surls J, Nazarov-Stoica C, Kehl M, Casares S, Brumeanu TD. Differential effect of CD4+Foxp3+ T-regulatory cells on the $\mathrm{B}$ and $\mathrm{T}$ helper cell responses to influenza virus vaccination. Vaccine 28, 7319-7330 (2010).

13. Qin L, Jiang G, Han J, Letvin NL. Regulatory $\mathrm{T}$ cells modulate DNA vaccine Immunogenicity at early time via functional CD4+ T cells and antigen duration. Front Immunol. 6, 510 (2015).

14. Wang SM, Tsai MH, Lei HY, Wang JR, Liu CC. The regulatory $\mathrm{T}$ cells in antiinfluenza antibody response post influenza vaccination. Hum Vaccin Immunother. 8, 1243-1249 (2012). 
15. Macatangay BJ, Szajnik ME, Whiteside TL, Riddler SA, Rinaldo CR. Regulatory T cell suppression of Gag-specific CD8 T cell polyfunctional response after therapeutic vaccination of HIV-1-infected patients on ART. PloS one 5, e9852 (2010).

16. Garner-Spitzer E, Wagner A, Paulke-Korinek M et al. Tick-borne encephalitis (TBE) and hepatitis B nonresponders feature different immunologic mechanisms in response to TBE and influenza vaccination with involvement of regulatory $\mathrm{T}$ and $\mathrm{B}$ cells and IL-10. J Immunol. 191, 2426-2436 (2013).

17. Perret R, Sierro SR, Botelho NK, Corgnac S, Donda A, Romero P. Adjuvants that improve the ratio of antigen-specific effector to regulatory $\mathrm{T}$ cells enhance tumor immunity. Cancer Res. 73, 6597-6608 (2013).

18. Iribarren K, Bloy N, Buque A et al. Trial Watch: Immunostimulation with Toll-like receptor agonists in cancer therapy. Oncoimmunology 5, e1088631 (2016).

19. Cerullo V, Diaconu I, Kangasniemi L et al. Immunological effects of low-dose cyclophosphamide in cancer patients treated with oncolytic adenovirus. Mol Ther. 19, 1737-1746 (2011).

20. Iellem A, Mariani M, Lang $\mathrm{R}$ et al. Unique chemotactic response profile and specific expression of chemokine receptors CCR4 and CCR8 by CD4(+)CD25(+) regulatory $\mathrm{T}$ cells. J Exp Med. 194, 847-853 (2001).

21. Bayry J, Tchilian EZ, Davies MN et al. In silico identified CCR4 antagonists target regulatory T cells and exert adjuvant activity in vaccination. Proc Natl Acad Sci USA. 105, 10221-10226 (2008).

22. Davies MN, Bayry J, Tchilian EZ et al. Toward the discovery of vaccine adjuvants: coupling in silico screening and in vitro analysis of antagonist binding to human and mouse CCR4 receptors. PloS one 4, e8084 (2009).

23. Pere H, Montier Y, Bayry J et al. A CCR4 antagonist combined with vaccines induces antigen-specific CD8+ T cells and tumor immunity against self antigens. Blood 118, 4853-4862 (2011).

24. Bayry J, Tartour E, Tough DF. Targeting CCR4 as an emerging strategy for cancer therapy and vaccines. Trends Pharmacol Sci. 35, 163-165 (2014).

25. Bosschem I, Bayry J, De Bruyne E et al. Effect of different adjuvants on protection and side-effects induced by Helicobacter suis whole-cell lysate vaccination. PloS one 10, e0131364 (2015).

26. Beziaud L, Mansi L, Ravel P et al. Rapalogs efficacy relies on the modulation of antitumor T-cell immunity. Cancer Res. 76, 4100-4112 (2016).

27. Davies MN, Pere H, Bosschem I et al. In Silico adjuvant design and validation. Methods Mol Biol. 1494, 107-125 (2017).

28. Klein A, Sagi-Assif O, Meshel T et al. CCR4 is a determinant of melanoma brain metastasis. Oncotarget doi: 10.18632/oncotarget.16076 (2017). 
29. Vitali C, Mingozzi F, Broggi A et al. Migratory, and not lymphoid-resident, dendritic cells maintain peripheral self-tolerance and prevent autoimmunity via induction of iTreg cells. Blood 120, 1237-1245 (2012).

30. Moise L, Gutierrez A, Kibria F et al. iVAX: An integrated toolkit for the selection and optimization of antigens and the design of epitope-driven vaccines. Hum Vaccin Immunother. 11, 2312-2321 (2015). 